\title{
Analisis Perbandingan Klasifikasi Support Vector Machine (SVM) dan K-Nearest Neighbors (KNN) untuk Deteksi Kanker dengan Data Microarray
}

\author{
Shidqi Aqil Naufal, Adiwijaya, Widi Astuti \\ Fakultas Informatika, Universitas Telkom, Bandung, Indonesia \\ Email: 1shidqiaqilnaufal@student.telkomuniversity.ac.id, 2adiwijaya@telkomuniversity.ac.id, \\ 3astutiwidi@telkomuniversity.ac.id
}

Submitted 03-02-2020; Accepted 09-02-2020; Published 15-02-2020

\begin{abstract}
Abstrak
Kanker adalah salah satu penyakit yang dapat menyebabkan kematian manusia di berbagai negara. Menurut WHO pada tahun 2018, kanker menyebabkan 9,6 juta kematian manusia di seluruh dunia. Secara global, sekitar 1 dari 6 kematian disebabkan oleh kanker. Oleh karena itu, diperlukan sebuah teknologi yang berguna untuk mendeteksi penyakit kanker dengan akurasi yang tinggi sehingga penyakit kanker dapat dideteksi sejak dini. Microarray mampu memprediksi beberapa jaringan tertentu pada manusia dan dapat dikelompokkan ke dalam kanker atau bukan. Namun, data microarray mempunyai suatu masalah yaitu dimensi yang dimiliki sangat besar. Untuk mengatasi hal tersebut pada penelitian ini digunakan salah satu teknik reduksi dimensi yaitu Partial Least Square (PLS) dan penggunaan Support Vector Machine (SVM) dan KNearest Neighbors sebagai metode klasifikasi. Sistem yang dibangun mampu menghasilkan akurasi tertinggi sebesar 98,54\% pada data leukemia dengan PLS-KNN, 100\% pada data lung dengan KNN, 66,52\% pada data breast dengan PLS-KNN, dan $85,60 \%$ pada data colon dengan PLS-SVM. KNN mampu mendapatkan akurasi terbaik di tiga data dari empat data yang diuji.
\end{abstract}

Kata Kunci: Kanker, Microarray, Partial Least Square (PLS), Suport Vector Machine (SVM), K-Nearest Neighbors(KNN)

\begin{abstract}
Cancer is a disease that can cause human death in various countries. According to WHO in 2018, cancer causes 9.6 million human deaths worldwide. Globally, about 1 in 6 deaths is due to cancer. Therefore, we need a technology that can be used for cancer detection with high acuration so that cancer can be detected early. Microarrays technique can predict certain tissues in humans and can be classified as cancer or not. However, microarray data has a problem with very large dimensions. To overcome this problem, in this study use one of the dimension reduction techniques, namely Partial Least Square(PLS) and use Support vector Machine (SVM) and K-Nearest Neighbors as a classification method, which will be used to compare which is better.The system built was able to reach $98.54 \%$ in leukemia data with PLS-KNN, $100 \%$ in lung data with KNN, $66.52 \%$ in breast data with PLS-KNN, and $85.60 \%$ in colon data with PLS- SVM. KNN is able to get the best in three data from four valued data.
\end{abstract}

Keywords: Cancer, Microarray, Partial Least Square (PLS), Suport Vector Machine (SVM), K-Nearest Neighbors(KNN)

\section{PENDAHULUAN}

Kanker adalah salah satu penyakit yang dapat menyebabkan kematian manusia di berbagai negara. Kanker menjadi penyebab utama kematian manusia dalam beberapa tahun terakhir. Menurut WHO pada tahun 2018, kanker menyebabkan 9.6 juta kematian manusia di seluruh dunia [1]. Secara global, sekitar 1 dari 6 kematian disebabkan oleh kanker. Namun, sekitar 30-50\% penyakit kanker dapat dicegah dengan menghindari faktor resiko utamanya seperti menghindari produk tembakau, mengurangi mengonsumsi alkohol dan berolahraga secara teratur[1, 24]. Pendeteksian kanker sejak dini sangat diperlukan agar upaya pencegahan dan pengobatan dapat dilakukan. Oleh karena itu, diperlukan sebuah teknologi yang berguna untuk mendeteksi penyakit kanker dengan akurasi yang tinggi agar penyakit kanker dapat dideteksi sejak dini.

Pada beberapa tahun terakhir, terdapat suatu analisis diagnosis kanker dengan menggunakan data microarray. Microarray adalah teknologi berbentuk chip yang digunakan untuk menentukan struktur dan fungsi berbagai macam gen yang ada pada tubuh manusia yang mempunyai jumlah yang sangat besar [2]. Microarray Teknologi microarray dapat digunakan sebagai diagnosis medis dan analisis gen. Dengan menganalisis ekspresi gen, dapat diketahui apakah seseorang terkena kanker atau tidak.

Microarray mampu memprediksi beberapa jaringan tertentu pada manusia dan dapat dikelompokkan ke dalam kanker atau bukan. Namun, data microarray mempunyai suatu masalah yaitu dimensi yang dimiliki sangat besar. Besarnya dimensi dapat berakibat pada tingkat performansi yang rendah. Untuk mengatasi permasalahan tersebut dapat dilakukan dengan mereduksi dimensi data microarray. Metode yang digunakan untuk ekstraksi fitur yaitu Partial Least Square (PLS) [3]. Untuk metode klasifikasi, akan digunakan metode Support Vector Machine (SVM) dan K-Nearest Neighbors [23]. Suport Vector Machine (SVM) mempunyai banyak fitur matematika yang membuatnya menarik untuk menganalisis ekspresi gen, mampu menangani permasalahan data set dan ruang fitur yang besar [4]. Metode K-Nearest Neighbor dapat digunakan untuk klasifikasi pada data microarray dan dapat menghasilkan hasil dengan akurasi yang tinggi [3,25].

Dalam penelitian kali ini, penulis mengambil referensi dari penelitian sebelumnya yang berkaitan dengan latar belakang pada penelitian ini. Berikut beberapa penelitian yang berhubungan dengan pengujian data 
microarray. Penelitian yang dilakukan pada tahun 2018 [5]. Pendekatan klasterisasi digunakan untuk mereduksi dimensi dengan metode $k$-means. Sedangkan untuk proses klasifikasi dilakukan dengan menggunakan metode random forest. Akurasi tertinggi untuk Kanker Usus Besar, Kanker Paru, dan Tumor Prostat dataset adalah $85,87 \%$, 98,9\%, dan 88,97\%. Penelitian selanjutnya dilakukan pada tahun 2018 [6]. Principal Component Analysis (PCA) digunakan dalam proses reduksi dimensi [21, 22] dan penggunaan Suport Vector Machine (SVM) dan Levenberg Marquardt based Back Propagation (LMBP) sebagai metode klasifikasi. Hasil akurasi yang didapat dengan LMBP sebesar 96,07\% sedangkan dengan SVM sebesar 94,98\%. Selanjutnya penelitian yang dilakukan pada tahun 2018 [7]. Penelitian ini digunakan untuk deteksi kanker berdasarkan data microarray. Mutual Information digunakan untuk mengatasi permasalahan tingginya dimensi pada data microarray. Kemudian, dilakukan klasifikasi dengan menggunakan Bayes Theorem. Hasil akurasi yang didapat adalah 91,06\% dengan Bayesian Network dan Naïve Bayes sebesar 88,85\%. Kemudian penelitian dilakukan tahun 2014 [8] yang berjudul "Gene expression data classification using Support Vector Machine and mutual informationbased gene selection”. Penelitian ini menggunakan dataset colon yang mana hasil terbesar akurasi yang didapat sebesar 97\% dengan menggunakan metode klasifikasi SVM dengan kernel linear. Penelitian terakhir dilakukan tahun 2015 yang berjudul "Cancer Detection Based On Microarray Data Classification Using PCA and MBP" [9]. Penelitian ini bertujuan untuk mendeteksi kanker berdasarkan data microarray. PCA dan MBP digunakan untuk mereduksi data microarray. Hasil akurasi yang dihasilkan untuk data ovarian sebesar 96\%, data colon $76,92 \%$ dan $97,14 \%$ untuk data leukemia.

Pada penelitian kali ini dibangun sebuah sistem klasifikasi untuk prediksi kanker berdasarkan data microarray. Dalam sistem ini digunakan dua metode klasifikasi yaitu Support Vector Machine (SVM) dan KNearest Neighbors (KNN) yang hasilnya akan dibandingkan metode klasifikasi mana yang mempunyai akurasi lebih baik. Terdapat empat data yang digunakan antara lain data breast cancer, lung cancer, colon tumor, dan leukemia yang didapat dari Kent Ridge Biomedical Data Repository [10]. Pada penelitian ini diuji beberapa skenario pengujian seperti efek penggunaan reduksi dimensi, pemilihan $\mathrm{k}$ tetangga pada KNN, dan pemilihan kernel pada SVM disertai parameter C, $d$, dan gamma.

\section{METODE PENELITIAN}

Pada penelitian digunakan Support Vector Machines dan K-Nearest neighbor untuk menentukan label kelas pada data microarray. Sedangkan untuk metode reduksi dimensi, akan digunakan Partial Least Square. Adapun skema sistem yang dibuat sebagai berikut:

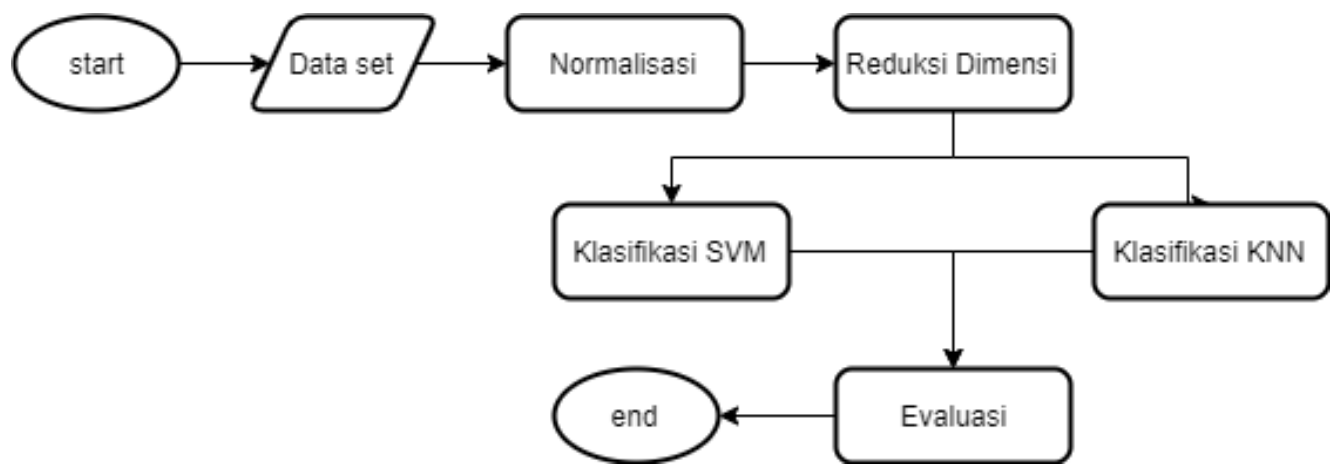

Gambar 1. Skema umum proses klasifikasi

Untuk mengklasifikasi kanker berdasarkan data microarray maka dibentuklah skema umum untuk mendukung proses klasifikasi. Terdapat lima proses yang dilakukan dalam proses klasifikasi antara lain normalisasi dataset, reduksi dimensi dengan menggunakan Partial Least square, lalu klasifikasi dengan Support Vector Machine dan K-Nearest Neighbors, kemudian analisis atau evaluasi hasil akurasi dari sistem.

Data yang digunakan adalah data breast cancer, lung cancer, colon tumor, dan leukemia yang didapat dari kent Ridge Biomedical Data Repository [10].

Tabel 1. Data set Kanker Kent Ridge Biomedical Data Repository

\begin{tabular}{lccc}
\hline \multicolumn{1}{c}{ Data } & Fitur & Jumlah Kelas & Sampel \\
\hline Breast Cancer & 24482 & 2 & 97 (46 Relapse, 51 non-relapse) \\
\hline Lung Cancer & 12533 & 2 & 181 (31 Mesothelioma, 150 ADCA) \\
\hline Colon Tumor & 2000 & 2 & 62 (22 Positif, 40 Negatif) \\
\hline Leukimia & 7129 & 2 & 72 (47 ALL, 25 AML) \\
\hline
\end{tabular}

Pada kolom pertama, terdapat 5 nama data yang digunakan untuk diklasifikasi. Pada kolom kedua terdapat jumlah sampel pada setiap datanya. Pada kolom ketiga terdapat jumlah fitur atau jumlah atribut pada setiap datanya. Pada kolom keempat terdapat jumlah kelas pada setiap datanya. Setiap data akan mempunyai dua 
kelas yang mengidentifikasi apakah setiap sampel data terkena kanker atau tidak. Jenis klasifikasi dapat diubah dengan angka biner, apabila terkena kanker dapat ditandai dengan angka 1 sedangkan 0 untuk menandai sampel yang tidak terkena kanker.

Proses pertama yang dilakukan adalah normalisasi data, nilai pada atribut di setiap data akan diubah range nilainya. Metode min-max akan digunakan untuk memperkecil range nilai pada setiap atributnya. Rumus umum untuk normalisasi data terdapat pada persamaan (1) [11]:

$$
\text { Normalisasi }=\frac{\text { data }-\min (\text { data })}{\max (\text { data })-\min (\text { data })}
$$

Proses ini akan menghasilkan nilai -1 sampai 1 pada setiap fitur dalam dataset yang diproses, sehingga rentang nilai yang dihasilkan tidak jauh.

Data microarray mempunyai karakteristik dimensi yang tinggi dan jumlah gen yang besar. Terdapat beberapa alasan pengurangan dimensi harus dilakukan yaitu, penurunan biaya pembelajaran, meningkatkan kinerja pembelajaran, mengurangi dimensi yang tidak relevan, mengurangi dimensi yang berlebihan [12]. Pengurangan kompleksitas bertujuan untuk meminimalisir kesalahan [13]. Hasil proses normalisasi, data akan masuk ke dalam proses reduksi dimensi dengan Partial Least Square.

Partial Least Square (PLS) adalah salah satu metode dalam mereduksi dimensi data [14]. Partial Least Square (PLS) dapat dikatakan juga teknik analisis multivariat untuk memprediksi variable depended dari satu set variabel independent [14]. Misalkan terdapat dua variabel yaitu X dan Y di mana Y adalah variabel dependen dan $\mathrm{X}$ adalah variabel independent (prediktor). Dengan adanya dua variabel $\mathrm{X}$ dan $\mathrm{Y}$, maka dengan menggunakan Partial Least Square akan mencari komponen X yang relevan terhadap Y. Partial Least Square memodelkan data dengan persamaan (1) dan (2) [15]:

$$
\begin{aligned}
& X=T P^{T} \\
& Y=U Q^{T}
\end{aligned}
$$

Di mana $\mathrm{X}$ adalah variabel prediktor, $\mathrm{T}$ dan $\mathrm{U}$ adalah matriks skor, $\mathrm{Y}$ adalah variabel dependen, $\mathrm{P}$ dan $\mathrm{Q}$ adalah matriks loading.

Dekomposisi $\mathrm{X}$ dan $\mathrm{Y}$ dilakukan untuk mengambil informasi satu sama lain. Caranya adalah dengan menukar $t$ dan $u$ untuk memperbarui nilai dari $w$ dan $q$ yang kemudian dilakukan pertukaran dan dilakukan berulang-ulang hingga $t$ tidak berubah. Adapun algoritma dari proses tersebut adalah sebagai berikut:

$$
\begin{aligned}
& u=y_{j} \text { for some } j \\
& \text { Loop } \\
& \qquad \begin{aligned}
w & =\frac{X^{T} u}{\left\|X^{T} u\right\|} \\
t & =X w \\
q & =\frac{Y^{T} t}{\left\|X^{T} t\right\|} \\
u & =Y q
\end{aligned}
\end{aligned}
$$

until t stop changing

Di mana $w$ adalah vector bobot dari $X, t$ adalah komponen kolom dari matriks $\mathrm{T}$ dan $u$ merupakan kolom dari matriks $U$. Persamaan yang digunakan untuk menghitung matriks loading $\mathrm{X}$ adalah persamaan (8):

$$
p=\frac{X^{T} t}{\| t^{T} t \mid}
$$

Persamaan di atas akan menghasilkan nilai pertama komponen dan matriks loading. Untuk mencari nilai selanjutnya, nilai X dan Y diatur kembali dengan persamaan (9) dan (10):

$$
\begin{aligned}
& X=X-t p^{T} \\
& Y=Y-u q^{T}
\end{aligned}
$$

Setelah melakukan proses di atas, maka akan didapatkan nilai p,t,q,u pada setiap perulangannya, di mana $\mathrm{t}$ adalah matriks hasil dari reduksi dimensi PLS. Hasil dari proses reduksi dimensi akan menghasilkan data dengan atribut yang lebih kecil yang selanjutnya akan diklasifikasi dengan SVM dan KNN.

Support Vector Machine adalah metode klasifikasi untuk membagi dua kelas berdasarkan pembagian hyperplane[16]. Penggunaan kernel pada metode SVM dapat menyelesaikan permasalahan data yang non-linear dengan memetakan data ke dimensi yang lebih besar. Proses untuk mencari hyperplane pada Support Vector Machine menurut Campbell sebagai berikut [17]:

a. Terdapat data $\overrightarrow{x_{l}} \in\left(\overrightarrow{x_{1}}, \overrightarrow{x_{2}}, \ldots \overrightarrow{x_{n}}\right)$ yang mana $x_{i}$ adalah data yang terdiri dari $\mathrm{n}$ atribut dan dua kelas $y_{i} \in$ $+1,-1$.

b. asumsi data linear dan kelas antara +1 dan -1 dapat dipisah oleh hyperplane. Kondisi ini dapat didefinisikan pada persamaan (11):

$$
\vec{w} \cdot \vec{x}+b=0
$$


Dari persamaan di atas akan diperoleh persamaan (12) dan (13):

$$
\begin{array}{r}
\vec{w} \cdot \vec{x}+b \geq 1 \text {, untuk kelas }+1 \\
\vec{w} \cdot \vec{x}+b \geq-1 \text {, untuk kelas }-1
\end{array}
$$

Di mana $\vec{w}$ sebagai weight, $\vec{x}$ sebagai data input, b adalah posisi bidang relatif.

c. Dalam menemukan hyperplane yang optimal, maka diperlukan mencari hyperplane pemisah yang memaksimalkan jarak antara dua kelas. Untuk itu pencarian titik minimal diperlukan. Adapun mencari titik minimal dapat dilakukan dengan persamaan (14):

dengan kendala pada persamaan berikut:

$$
\min _{w} \frac{1}{2}(\| \vec{w}||)^{2}
$$

$$
y_{i}\left(\overrightarrow{x_{l}}, \vec{w}+b\right)-1 \geq 0
$$

Di mana $\overrightarrow{x_{\imath}}$ adalah data input ke- $i, \vec{w}$ adalah weight, $\mathrm{b}$ adalah posisi bidang relatif, dan $y_{i}$ adalah kelas target ke-i.

d. Untuk mengatasi data yang non-linear maka akan digunakan kernel yang akan mentransformasikan dari input space ke dalam feature space.

$$
\begin{gathered}
\text { Linier : } K\left(\vec{x}_{i}, \vec{x}_{j}\right)=\left(\vec{x}_{i}, \vec{x}_{j}\right) \\
\text { Radial Basis Function(RBF) : } K\left(\vec{x}_{i}, \vec{x}_{j}\right)=\exp \left(-\frac{|| \vec{x}_{i}-\left.\vec{x}_{j}\right|^{2}}{2 \sigma^{2}}\right) \\
\text { Polinomial : } K\left(\vec{x}_{i}, \vec{x}_{j}\right)=\left(\vec{x}_{i}, \vec{x}_{j}+c\right)^{d}
\end{gathered}
$$

Di mana $\vec{x}_{i}$ dan $\vec{x}_{j}$ adalah vector dari ruang fitur, $d$ adalah degree, $\sigma$ gamma dan c adalah parameter bebas. Pemilihan parameter bebas sangat penting, karena nilai parameter yang dipilih dapat mengakibatkan overfitting pada data.

K-Nearest Neighbors merupakan metode klasifikasi yang termasuk dalam supervised learning berdasarkan data pembelajaran yang akan dikelompokkan berdasarkan kedekatan jarak dengan objek tersebut. Untuk mengukur jarak antar titik dapat digunakan euclidean distance (19) [18].

$$
d=\sqrt{\Sigma\left(x_{i}-y_{i}\right)^{2}}
$$

Euclidean distance sering digunakan untuk pengukuran jarak pada matriks dengan memberikan titik ke kelas di antara $\mathrm{k}$ tetengga yang terdekat di mana $\mathrm{k}$ adalah bilangan bulat.

Dalam klasifikasi dengan metode $K$-Nearest Neigbors, dataset yang digunakan adalah dataset hasil dari proses preprocessing pada tahap sebelumnya. Setelah memasukkan dataset, tentukan k sebagai parameter. Penentuan $\mathrm{k}$ sebagai parameter berguna untuk menentukan jumlah tetangga yang akan diambil saat proses klasifikasi. Langkah selanjutnya adalah dengan menghitung Euclidean distance dari objek yang akan dicari kelasnya dengan semua sampel data. Kemudian, lakukan proses sorting secara ascending untuk setiap hasil Euclidean distance yang sebelumnya sudah dicari. Pada tahap akhir, hitung kelas mayoritas pada rentang k yang sebelumnya sudah dijadikan parameter pada langkah pertama. Kelas terbanyak, akan menjadi kelas pada objek yang diklasifikasikan. Pada proses ini akan dihasilkan kelas prediksi pada data test yang diuji.

Setelah melalui tahap klasifikasi, akan diluakan perhitungan akurasi. Perhitungan akurasi merupakan perhitungan untuk menentukan seberapa baik akurasi dari sistem yang telah dibuat. Dalam klasifikasi, perhitungan akurasi akan dilakukan dengen membandingkan jumlah klasifikasi data yang benar dengan jumlah data keseluruhan dan akan dikalikan dengan $100 \%$. Persamaan perhitungan akurasi dapat dihitung dengan rumus (20):

$$
\text { Akurasi }=\frac{\text { jumlah data benar }}{\text { jumlah data keseluruhan }} \times 100 \%
$$

Perhitungan akurasi dilakukan pada setiap metode klasifikasi yang digunakan. Setelah mendapatkan akurasi masing masing metode, maka akan dibandingkan mana yang lebih baik antara kedua metode tersebut apabila digabungkan dengan metode reduksi dimensi Partial Least Square.

\section{HASIL DAN PEMBAHASAN}

Pada penelitian ini digunakan empat dataset yang tertera pada Tabel 1. Implementasi dilakukan dengan menggunakan K-Fold dengan $\mathrm{k}=11$. K-Fold merupakan teknik untuk membagi dataset menjadi $\mathrm{k}$-buah partisi secara acak yang kemudian dilakukan sejumlah k-kali eksperimen dimana setiap eksperimen mengggunakan data partisi ke-k sebagai data testing dan sisa partisi lainnya sebagai data train [19]. Sehingga akurasi sistem akan dihitung dari rata-rata setiap iterasi. Pada proses klasifikasi, akan digunakan K-Neighbors 3,5,7,9, dan 11 
pada metode K-Nearest Neighbors.Pada Support Vector Machine digunakan tiga kernel yaitu linear, Radial Basis function, dan polynomial. Ada beberapa parameter yang digunakan antara lain: $\mathrm{C}=[0.1,1], \mathrm{d}=[2,3,4,5]$, dan gamma $=[1,0.1,0.001,0.00001]$ [20]. Pada penelitian ini dilakukan 8 skenario pengujian untuk mengetahui hasil akurasi dari proses klasifikasi. Empat skenario pertama dilakukan dengan memprediksi kelas dengan metode KNN, SVM kernel linear, SVM kernel Polynomial, dan SVM kernel Radial Basis Function dengan tidak menggunakan reduksi dimensi yaitu Partial Least Square. Pada proses reduksi dimensi digunakan 30 komponen untuk semua data yang digunakan. Pada skenario yang lain, digunakan metode klasifikasi yang sama, namun dengan menggunakan Partial Least Square sebagai metode reduksi dimensi. Sebagai perbandingan, ditambahkan hasil akurasi dengan metode PCA sebagai metode reduksi dimensi dan SVM sebagai metode klasifikasi yang hasilnya didapat dari penelitian [6]

\subsection{Hasil Akurasi Data Leukimia}

Hasil akurasi yang dihasilkan dari beberapa skenario pengujian pada data leukimia sebagai berikut.

Tabel 2. Perbandingan Hasil Akurasi Data Leukimia

\begin{tabular}{llccc}
\hline & KNN & SVM-Linear & $\begin{array}{l}\text { SVM- } \\
\text { Polynomial }\end{array}$ & SVM-RBF \\
\hline No PLS & $98,22 \% \mathrm{k}=11$ & $98,22 \%$ & $53,84 \% \mathrm{~d}=2$ & $53,84 \%$ \\
\hline PLS & $98,54 \% \mathrm{k}=5$ & $95,32 \%$ & $93,32 \% \mathrm{~d}=3$ & $95,51 \%$ \\
\hline PCA [7] & $98,02 \% \mathrm{k}=11$ & $100 \%$ & $73,33 \% \mathrm{~d}=3$ & $100 \%$ \\
\hline
\end{tabular}

Pada data leukemia Hasil akurasi tertinggi dari pengujian yang telah dilakukan adalah sebesar 98,22\% pada metode KNN dengan $\mathrm{k}=11$ dan 98,22\% pada metode SVM dengan kernel linear tanpa melalui reduksi dimensi, sedangkan yang menggunakan proses reduksi dimensi dihasilkan akurasi tertinggi sebesar $98.54 \%$ pada metode KNN dengan $\mathrm{K}=5$ dan 95,51\% pada metode SVM kernel RBF. Walaupun saat tidak menggunakan PLS akurasi mencapai 98,22\%, namun hasil akurasi yang dihasilkan tidak stabil. Proses reduksi dimensi pada data leukemia, dapat menghasilkan akurasi yang stabil pada semua metode. Hal ini dikarenakan data hasil reduksi dimensi menghasilkan data yang informatif. Sebagai perbandingan, pada penelitian [6] akurasi menggunakan PCA sebagai metode reduksi dimensi dan SVM sebagai klasifikasi mampu mencapai $100 \%$ pada SVM linear dan SVM-RBF. Pada PCA KNN dilakukan pembuatan sistem oleh penulis dan mendapatkan akursi sebesar 98,02\%.

\subsection{Hasil Akurasi Data Lung}

Hasil akurasi yang dihasilkan dari beberapa skenario pengujian pada data lung sebagai berikut.

Tabel 3. Perbandingan Hasil Akurasi Data Lung

\begin{tabular}{lcccc}
\hline & KNN & SVM-Linear & $\begin{array}{l}\text { SVM- } \\
\text { Polynomial }\end{array}$ & SVM-RBF \\
\hline No PLS & $100,00 \% \mathrm{k}=5$ & $98,72 \%$ & $83,35 \% \mathrm{~d}=2$ & $85,50 \%$ \\
\hline PLS & $97,39 \% \mathrm{k}=1$ & $98,83 \%$ & $98,83 \% \mathrm{~d}=3$ & $89,34 \%$ \\
\hline PCA [7] & $100 \% \mathrm{k}=5$ & $93,75 \%$ & $75 \% \mathrm{~d}=3$ & $90,63 \%$ \\
\hline
\end{tabular}

Pada data lung hasil akurasi tertinggi dari pengujian yang telah dilakukan adalah sebesar $100 \%$ pada metode KNN dengan $\mathrm{k}=5$ dan $98.72 \%$ pada metode SVM dengan kernel linear tanpa melalui reduksi dimensi, sedangkan yang menggunakan proses reduksi dimensi dihasilkan akurasi tertinggi sebesar $97.39 \%$ pada metode KNN dengan $\mathrm{K}=1$ dan $98.83 \%$ pada metode SVM kernel linear dan polynomial. Pada data lung, hasil akurasi sebelum dan sesudah direduksi dimensi cenderung stabil. Hal ini dikarenakan data lung, tidak terlalu noise sehingga dapat menghasilkan akurasi yang cukup baik walaupun tidak melalui hasil reduksi dimensi. Sebagai perbandingan, pada penelitian [6] akurasi menggunakan PCA sebagai metode reduksi dimensi pada data lung mampu mencapai $100 \%$ pada KNN. Pada PCA KNN dilakukan pembuatan sistem oleh penulis dan mendapatkan akursi sebesar $98,02 \%$.

\subsection{Hasil Akurasi Data Breast}

Hasil akurasi yang dihasilkan dari beberapa skenario pengujian pada data breast sebagai berikut.

Tabel 4. Perbandingan Hasil Data Breast

\begin{tabular}{llclc}
\hline & KNN & SVM-Linear & $\begin{array}{l}\text { SVM- } \\
\text { Polynomial }\end{array}$ & $\begin{array}{l}\text { SVM- } \\
\text { RBF }\end{array}$ \\
\hline No PLS & $57,40 \% \mathrm{k}=1$ & $53,12 \%$ & $53,12 \% \mathrm{~d}=2$ & $53,12 \%$ \\
\hline PLS & $66,52 \% \mathrm{k}=9$ & $52,32 \%$ & $60,90 \% \mathrm{~d}=2$ & $56,16 \%$ \\
\hline PCA & $61,46 \% \mathrm{k}=1$ & $65,56 \%$ & $66,51 \% \mathrm{~d}=3$ & $68,40 \%$ \\
\hline
\end{tabular}


Pada data breast Hasil akurasi tertinggi dari pengujian yang telah dilakukan adalah sebesar 57,40\% pada metode KNN dengan $\mathrm{k}=1$ dan $53,12 \%$ pada metode SVM dengan kernel linear, polynomial, dan RBF tanpa melalui reduksi dimensi, sedangkan yang menggunakan proses reduksi dimensi dihasilkan akurasi tertinggi sebesar $66,52 \%$ pada metode $\mathrm{KNN}$ dengan $\mathrm{K}=9$ dan $60,90 \%$ pada metode SVM kernel linear dan 56,16\% di kernel polynomial. Hasil akurasi sebelum reduksi dimensi maupun sesudah cenderung stabil namun tidak terlalu baik. Noise yang terdapat pada data breast, tidak mampu diatasi dengan proses reduksi dimensi dengan PLS. Proses reduksi dimensi menggunakan PCA, akurasi yang dihasilkan mirip dengan menggunaan PLS.

\subsection{Hasil Akurasi Data Colon}

Hasil akurasi yang dihasilkan dari beberapa skenario pengujian pada data colon sebagai berikut.

Tabel 5. Perbandingan Hasil Data Colon

\begin{tabular}{ccccc}
\hline & KNN & SVM-Linear & $\begin{array}{l}\text { SVM- } \\
\text { Polynomial }\end{array}$ & SVM-RBF \\
\hline No PLS & $85,50 \% \mathrm{k}=7$ & $77,33 \%$ & $64,59 \% \mathrm{~d}=2$ & $64,59 \%$ \\
\hline PLS & $76,64 \% \mathrm{k}=5$ & $70,79 \%$ & $77,17 \% \mathrm{~d}=3$ & $85,60 \%$ \\
\hline PCA [7] & $85,48 \% \mathrm{k}=9$ & $85,71 \%$ & $85,71 \% \mathrm{~d}=3$ & $85,71 \%$ \\
\hline
\end{tabular}

Pada data breast Hasil akurasi tertinggi dari pengujian yang telah dilakukan adalah sebesar $85,50 \%$ pada metode KNN dengan $\mathrm{k}=7$ dan $77,33 \%$ pada metode SVM dengan kernel linear tanpa melalui reduksi dimensi, sedangkan yang menggunakan proses reduksi dimensi dihasilkan akurasi tertinggi sebesar 76,64\% pada metode KNN dengan K=5 dan 85,60\% pada metode SVM kernel linear dan polynomial. Hasil akurasi yang didapat pada proses sesudah reduksi dimensi cenderung lebih stabil dibandingkan sebelum direduksi dimensi. Namun dibandingkan dengan penelitian [6] hasil akurasi dengan menggunakan PCA lebih stabil dibandingkan dengan menggunakan PLS. Pada PCA KNN dilakukan pembuatan sistem oleh penulis dan mendapatkan akurasi sebesar $85,48 \%$.

\subsection{Analisis Pengujian}

Berdasarkan skenario pengujian yang telah dilakukan, proses reduksi dimensi dengan menggunakan metode Partial Least Square dapat membantu menaikkan akurasi dari hasil proses klasifikasi. Namun, di beberapa percobaan yang dilakukan, proses reduksi dimensi justru membuat akurasi dari sistem menurun. Salah satu sebabnya adalah data yang tidak informatif ikut diproses dalam proses reduksi dimensi [6]. Data yang tidak berguna cenderung memiliki nilai varians yang kecil sehingga mengganggu data informatif lainnya dan dapat memengaruhi hasil klasifikasi.

Pada hasil pengujian terhadap empat data kanker, metode KNN mampu menghasilkan hasil akurasi tertinggi di tiga dataset yaitu data leukemia, data lung, dan data breast. Pada data leukemia dan data breast, akurasi tertinggi didapat setelah melalui proses reduksi dimensi. Sedangkan pada data lung, akurasi tertinggi didapat tanpa melalui reduksi dimensi. Sifat KNN yang non linear menjadi salah satu kelebihan dalam proses klasifikasi data kanker yang telah diuji. Selain itu tidak adanya data pencilan menjadi salah satu alasan hasil akurasi dari KNN cukup baik.

Pada metode SVM dapat memprediksi dengan akurasi tertinggi pada data colon. Kernel yang digunakan untuk mencapai akurasi tertinggi adalah $\mathrm{RBF}$ di mana dengan parameter $\mathrm{C}=1$ dan gamma=1 yang mana sebelumnya melalui proses reduksi dimensi. Walaupun SVM mampu menangani permasalahan data set dan ruang fitur yang besar [4], SVM mempunyai kelemahan yaitu dalam memilih nilai parameter yang optimal. SVM sangat sensitive terhadap pemilihan parameter yang digunakan. Hal itu yang menyebabkan pada penelitian ini, KNN mampu mendapatkan akurasi tertinggi di tiga data dari empat data yang diuji. Untuk itu diperlukan penelitian lebih lanjut terhadap parameter lain guna mendapatkan parameter yang baik untuk mendapatkan hasil akurasi yang maksimal.

\section{KESIMPULAN}

Microarray adalah teknologi yang digunakan untuk menentukan struktur dan fungsi berbagai macam gen yang ada pada tubuh manusia yang mempunyai jumlah yang sangat besar. Dengan menganalisis ekspresi gen, dapat diketahui apakah seseorang terkena kanker atau tidak. Pada data microarray terdapat masalah yaitu dimensi yang sangat besar. Pada penelitian ini digunakan metode Partial least Square untuk mereduksi dimensi dan digunakan KNN dan SVM dalam klasifikasi data. Proses reduksi dimensi sangat berpengaruh pada hasil akurasi. Dari empat data yang diklasifikasi, tiga data mempunyai akurasi tertinggi setelah melalui proses reduksi dimensi yang mana pada data leukem, ia mempunyai akurasi tertinggi 98,54\% dengan metode klasifikasi $\mathrm{KNN}$ dengan $\mathrm{k}=5$. Data breast mempunyai akurasi 66,52\% dengan klasifikasi KNN dengan k=9. Data colon dengan klasifikasi SVM kernel RBF mempunyai akurasi $85,60 \%$ dengan parameter $\mathrm{C}=1$ dan gamma $=1$. Adapun pada data lung, 
akurasi tertinggi didapatkan tanpa melalui proses reduksi dimensi yaitu 100\% dengan metode KNN dengan k=5. Penentuan jumlah komponen yang tepat saat proses reduksi dimensi diperlukan guna menghasilkan akurasi yang maksimal saat proses klasifikasi. Selain itu menentukan parameter k pada KNN juga berpengaruh pada hasil akurasi proses klasifikasi. Pada SVM kombinasi yang tepat antara penggunaan kernel dan parameter yang digunakan seperti $\mathrm{C}, d$, dan gamma juga dapat meningkatkan akurasi dari sistem yang telah dibuat.

\section{UCAPAN TERIMAKASIH}

Dengan selesainya penelitian ini, penulis mengucapkan terima kasih kepada Prof. Dr. Adiwijaya, S.Si., M.Si., Widi Astuti, S.T., M.Kom. selaku pembimbing dan semua pihak yang telah banyak memberikan bantuan serta motivasi dalam penyelesaian penelitian ini sehingga berjalan dengan lancer dan sukses.

\section{REFERENCES}

[1] A.n, "Cancer Key Facts," World Health Organization, 2018. [Online]. Available: https://www.who.int/news-room/factsheets/detail/cancer. [Accessed: 17-Feb-2019].

[2] A. M. Sarhan, "Cancer Classification Based on Microarray Gene Expression Data Using DCT and ANN," J. Theor. Appl. Inf. Technol., pp. 208-216, 2009.

[3] S. Deegalla and H. Bostrom, Classificarion of Microarrays with KNN: Comparison of Dimensionality Reduction Methods, vol. 8206, no. April. European Conference on Machine Learning, 2013.

[4] M. P. S. Brown et al., "Knowledge-based analysis of microarray gene expression data by using support vector machines.," Proc. Natl. Acad. Sci. U. S. A., vol. 97, no. 1, pp. 262-267, 2000.

[5] H. Aydadenta, Adiwijaya, "A Clustering Approach for Feature Selection in Microarray Data Classification using Random," J. Inf. Process. Syst., vol. 14, no. 5, pp. 1167-1175, 2018

[6] D. S. Kusumo, Adiwijaya, U. N. Wisesty, A. Aditsania, and E. Lisnawati, "Dimensionality Reduction using Principal Component Analysis for Cancer Detection based on Microarray Data Classification,” J. Comput. Sci., vol. 14, no. 11, pp. 1521-1530, 2018.

[7] M. D. Purbolaksono, K. C. Widiastuti, M. S. Mubarok, Adiwijaya, and F. A. Ma'ruf, "Implementation of mutual information and bayes theorem for classification microarray data," J. Phys. Conf. Ser., vol. 971, no. 1, 2018.

[8] C. Devi Arockia Vanitha, D. Devaraj, and M. Venkatesulu, "Gene expression data classification using Support Vector Machine and mutual information-based gene selection," Procedia Comput. Sci., vol. 47, no. C, pp. 13-21, 2014

[9] A. Nurfalah, Adiwijaya, and A. A. Suryani, "Cancer detection based on microarray data classification using PCA and modified back propagation," Far East J. Electron. Commun., vol. 16, no. 2, pp. 269-281, 2016

[10] "Elvira Biomedical Dataset Repository." [Online]. Available: http://leo.ugr.es/elvira/DBCRepository/. [Accessed: 06-Apr-2019].

[11] P. S. Ord, Methods in microarray normalization. CRC Press, 2008

[12] O. Maimon and L. Rokach, Data Mining and Knowledge Discovery Handbook. 2008

[13] Adiwijaya, "Deteksi Kanker Berdasarkan Klasifikasi Microarray Data," Media Inform. Budidarma, vol. 2, no. 4, pp. 181-186, 2018.

[14] D. M. Pirouz, "An Overview of Partial Least Squares," Ssrn, no. March, 2010

[15] K. S. Ng, “A Simple Explanation of Partial Least Squares,” pp. 1-10, 2013.

[16] R. Dehak, N. Dehak, P. Kenny, and P. Dumouchel, "Kernel combination for SVM speaker verification," Proc. Speak. Lang. Recognit. Work., no. x, pp. 1-5, 2008.

[17] C. Campbell, Support Vector Machine and Kernel Methods. 2005

[18] L. Y. Hu, M. W. Huang, S. W. Ke, and C. F. Tsai, "The distance function effect on k-nearest neighbor classification for medical datasets," Springerplus, vol. 5, no. 1, 2016.

[19] P. Refaeilzadeh, L. Tang, and H. Liu, "Cross Validation,” Australas. Inst. Min. Metall. Publ. Ser., pp. 13-18, 2005.

[20] D. Jia, D. Zhang, and N. Li, "with Gaussian Time Warp Edit Distance Kernel," Comput. Math. Methods Med., vol. 2014, no. 10, 2014.

[21] Adiwijaya, U. N. Wisesty, E. Lisnawati, A. Aditsania, D. S. Kusumo, "Dimensionality Reduction using Principal Component Analy sis for Cancer Detection based on Microarray Data Classification", Journal of Computer Science 14(11), 2018

[22] Astuti, W., \& Adiwijaya, A. (2019). "Principal Component Analysis Sebagai Ekstraksi Fitur Data Microarray Untuk Deteksi Kanker Berbasis Linear Discriminant Analysis". JURNAL MEDIA INFORMATIKA BUDIDARMA, 3(2), 72-77. 2019

[23] Ma'ruf, F. A., Adiwijaya \& Wisesty, U. N. "Analysis of the influence of Minimum Redundancy Maximum Relevance as dimensionality reduction method on cancer classification based on microarray data using Support Vector Machine classifier". In Journal of Physics: Conference Series (Vol. 1192, No. 1, p. 012011). IOP Publishing, 2019.

[24] Manik, A., Adiwijaya, A., \& Utama, D. Q. "Classification of Electrocardiogram Signals using Principal Component Analysis and Levenberg Marquardt Backpropagation for Detection Ventricular Tachyarrhythmia". Journal of Data Science and Its Applications, 2(1), 78-87, 2019

[25] Mabarti, I., Aditsania, A., "Implementation of Minimum Redundancy Maximum Relevance (MRMR) and Genetic Algorithm (GA) for Microarray Data Classification with C4.5 Decision Tree". Journal of Data Science and Its Applications, 3(1), 2020. 